\title{
Re-Constructed Unitary History on Green Island, Taiwan: The Former Political Prison/Oasis Villa
}

\author{
H. W. Lin
}

\begin{abstract}
Former sites of torture and imprisonment converted to prison museums play an important role in forming the testimony underlying the history and national identity of Taiwan's contested past. Oasis Villa, an extension of the existing New Life Correction Centre on Green Island, was also known as the Green Island Disciplinary Education Prison. Political prisoners who opposed the ruling government were imprisoned here, and it was a final destination for victims transported from prisons in Taiwan during the period of Martial Law.

This paper examines the reconstructed history as represented by museum exhibition. This produces an ambivalent memory of, and one-sided perspective on, the experiences of the surviving victims. This paper analyses the history as reconstructed from the memory of a single source, and this depicts a partial picture of the prison through interpretations that form museum exhibitions that anesthetise the former site of punishment and incarceration. These findings reveal a past ignored by the binary oppositions of living memory which constitutes the difficult past and its transformation. This research also discusses the representation and interpretation of the political prison as it is transformed to the Green Island Human Rights Cultural Park, and its role in the modern society of Taiwan.
\end{abstract}

Index Terms-Political prison, martial law, representation, museum.

\section{INTRODUCTION}

Taiwan, also known as Formosa, is an island off the south eastern coast of China. In 1949, four years after the end of World War II, Martial Law was imposed in Taiwan, following Chiang Kai-Shek's flight to the island after his defeat on mainland China. The Taiwan Garrison Command, together with other secret agencies, were order to arrest anyone who voiced opposition to government policy. Martial Law was lifted in 1987 after the passing of the "National Security Law", which also contained a significant number of restrictions on freedom of assembly and association, and on political rights. Other, still existing, laws effectively limit the freedom of speech and of the press [1].

The Nationalist Party of China (KMT) established their own Chinese government-in-exile, with the aim of retaking mainland China in the future, and therefore regarded Taiwan as no more than a small province. [2] When the Republic of China took over Taiwan in 1945, it produced the one-party political tutelage system brought over from China. In 1948, the regime drafted the Temporary Provisions Effective

Manuscript received December 14, 2013; revised February 11, 2014. This work was supported in part by the National Science Council Research Project Grant 102-2221-E-006-228.

H. W. Lin is with the National Cheng Kung University, Taiwan (e-mail: hwlin@mail.ncku.edu.tw). during the Period of National Mobilisation for Suppression of the Communist Rebellion, and followed this by imposing Martial Law throughout Taiwan. This period of Martial Law lasted for 38 years. With legislation such as the Offenses against the Internal Security of the State in the Criminal Code, the Betrayers Punishment Act and Statute to Prevent Espionage, the government and its various secret agencies and military tribunals, created a climate in which improper trials were common place. This resulted in loss of life, freedom and property, and serious, and ongoing, violations of human rights. During the period of Martial Law, the government, police or security forces were involved in torture; the harsh treatment, including psychological pressure, of detainees; surveillance and harassment of the relatives and other associates of the dissidents; and the sentencing for an average of 10 years of several hundred political prisoners. Of those affected during the period only a minority were actually "Communist agents" or engaging in "rebellion" as defined by law, most were falsely accused, or the victims of mistakes or fabricated cases. Individuals could be either sentenced to death and executed, or sent to prison. The best preserved of the prisons from this period are the Military Prison situated on the outskirts of Taipei and the prison on Green Island.

\section{THE OASIS VILLA}

Green Island is known to be the furthest eastward settlement of the Chinese migrations of the 17 century, and is 33 kilometres from the southeast coast of Taiwan. It was originally named Burnt Island, and is an island of volcanic rock, surrounded by a fringe of coral reef. Prison history on Green Island covers over a century. In the Japanese colonial period (1895-1945), there was the "Burnt Island Detention Centre for Vagrants" built between 1911 and 1919. During the Martial Law period, the prison complex went through several stages. The Burnt Island Detention Centre for Vagrants of the Japanese colonial period (1895-1945) (See Fig. 1) was, after WWII, re-established by the ruling government of the KMT as prisons for political prisoners. It was renamed the "New Life Correction Centre" (1951-1965, this meaning "prison"), and later the Ministry of National Defence Green Island Reform and Re-education Prison (1972-1987, also known as Oasis Villa), and the Taiwan Garrison Command Headquarters (1949-1992) (See Fig. 2). It reflects the isolated position of Taiwan during the Cold War, having been constructed to house political prisoners and used as a forced labour camp at a time of rising awareness concerning human rights. This awareness was in addition to the international movements for the release of political prisoners in Taiwan. 


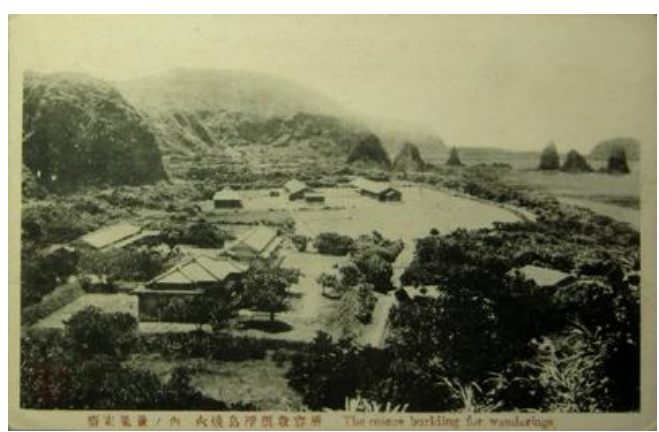

Fig. 1. Burnt island detention centre for vagrants.

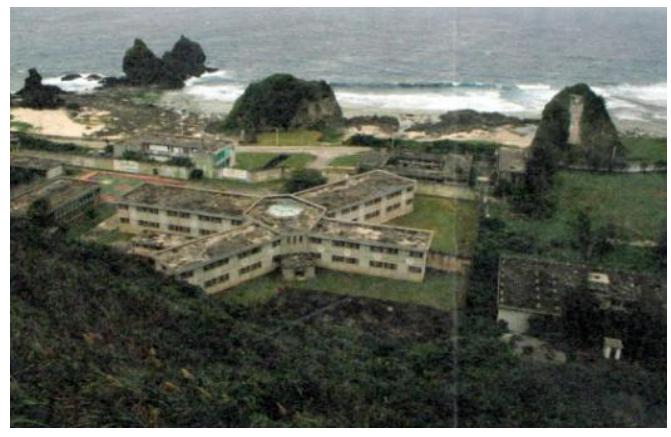

Fig. 2. Oasis villa. courtesy of Hisao-Hsia pan.

The New Life Correction Centre was the largest labour camp for political prisoners, comprising both cell blocks and guard barracks. During the first fifteen years of Martial Law, the continually rising numbers of political prisoners were moved from ordinary prisons to the Ministry of National Defence Military Prison. Most of them were sent to Green Island for a regime of hard labour 'thought reform'. From 1951 to 1954 there were 2000 prisoners, including 100 women, as well as a number of prisoners who were refugees from China. The population of the prison reached 3000, including prison staff, which equalled the indigenous population of Green Island. In the early stages the labouring work included the felling of trees on the mountains, breaking up the reef rocks on the beach, and constructing cells, barracks and sheds for the prisoners themselves. At the end of the Korean War, prisoners were forced to "volunteer" to show loyalty by tattooing on their bodies slogans such as "Oppose the Communists, Resist the Russians." In 1972, the Ministry of National Defence Green Island Reform and Re-education Prison was built on the west side of the New Life Correction Centre (Oasis Villa). This had particularly high walls and was urgently needed to accommodate more prisoners sent from Tai-Yuan Prison, and additional military prisoners from all over mainland Taiwan.

The Oasis Villa was built in reinforced concrete with a" $\Pi$ "shape administration building and razor wire on the top of the walls, and comprised a two- storey radial layout of cells and an eight-trigrams shaped central court. It is symbolic of the totalitarian regime during the time of Martial Law, and it housed many hundreds of political prisoners up until the end of the law in 1987. In the following decade, new buildings were built for a drug addict rehabilitation centre, and for stubborn prisoners. In 1997, the Ministry of Justice ordered the renovation of existing prison buildings to expand the capacity of the original prison cells. During this time, a documentation centre focussing on the prison's contested history was proposed by lawmaker Mr Ming-Te Shi together with 16 prominent public figures. Mr Ming-Te Shi had been detained in the New Life Correction Centre between 1974 and 1977, and he discovered that the Oasis Villa building complex had sustained serious damage during renovation. This renovation was temporarily stopped for further assessment by the Executive Yuan. After one year of negotiation a conservation plan for Oasis Villa was proposed. A public hearing on "Augmentation of the Museum of White Terror- Keeping the Oasis Villa" was held, and this resulted in four demands. These were: first, the renovation work should be completely stopped; second, the Oasis Villa should be planned as a memorial or museum; third, an investigation team should be established; fourth, a cross-sector team committee should be established. By the end of 1996, more than 400 people had given their support to constructing a memorial. After one year of recruiting sponsors and allocating the design plan for the memorial, it was officially inaugurated in December 1999. At the end of 2002, the plan for the Green Island Human Rights Memorial Park (GIHRMP) was officially signed off. This current plan is aimed at "eco-tourism" rather than retaining the site as a place of reflection on a difficult history. The 'Green Island Human Rights Memorial Park' embedded in its meaning the exclusion of the period of Martial Law, or evidential spaces of Martial Law such as the prisons. The New Life Correction Centre was not included in the memorial site until the former political prisoners who were also the members of 'The Accelerate Committee for White Terror in 50s' Rehabilitate' protested in 2002. Even then, when the Executive Yuan re-adjusted the "Green Island Human Rights Memorial Park Project Team" to expand the site further, this still excluded the prison.

The GIHRMP constitutes buildings built in different periods and also managed by different organisation. There is the Oasis Villa building complex (administration building, auditorium, detention cells, eight-trigram central court, solitary confinement, kitchen, and exercise yards, and special observation and medical room); the Juan-Jing Camp, the Green Island Skill Training Centre and complex; the Coast Guard Administration; and lastly, some relics of the prison. The stewardship of the memorial site was originally given to the Tourism Bureau- the Office of East Coast National Scenic Area. In 2006 the Council of Cultural Affairs took over the stewardship of the memorial site and the Oasis Villa was designated as a Historic Building [3].

\section{Site EMbodied WITH INTELLIGENCE AND HORROR While PRESENTING ABSENCE IN CHAPTERS OF LIFE}

The constituents of GIHRMP are from two major prisons built in two stages, the New Life Correction Centre and Oasis Villa. These are the places where visitors can map information from the comprehensive records of the dark era during Martial Law over the surrounding contemporary landscape.

The New Life Correction Centre was organized into 3 brigades, each comprising four squadrons. Groups of political prisoners were ferried in and out of the island over a period of 15 years. Conditions were harsh and, during a 
rebellion in July 1953, 16 prisoners were executed for 'recidivist incident'. The New Life Correction Centre was typical of the concentration camp aimed at 'reform' spawned during the cold war. Political Prisoners had to hammer off coral reef from the coast to build high walls, (due to demolition by the Ministry of Defence this high wall built by prisoners no longer exists and can only be imagined) [4]. In addition, prisoners were also required to build the "Overcoming Adversity" shed, speech platform, and warehouses. There were two types of "Overcoming Adversity" Shed, ones of approximately 142 square metres, and smaller ones of 50 square metres. The roof trusses were constructed from trees felled by prisoners, with the roofs covered with grass. Each squadron has several sheds which were used for storing grain, cooking utensils and farming implements, as well as for raising pigs and turkeys.

The term "new lifer" was given to the political prisoners, with an implication of "restart." They were prohibited to call themselves "prisoners", instead, they were only allowed to address each other as "classmate." They were not only assigned to punishing amounts of hard manual labour, but were mentally under extreme stress as the result of being strictly controlled and sifted for information. It was the intention that the hard labour would result in prisoners suffering physical exhaustion and this would repress free thought.

Over 3000 political prisoners and refugees jailed during Martial Law faced this daily brutality, psychological terror and hard manual labour. A civilian resident of the island, $\mathrm{Mr}$ Hui-Hung Tien (2011) stated that they were told not to talk to the 'new lifers' by any means as they were spies, but they slowly discovered that they were professionals in many fields, and had a high degree of knowledge between them all. There were prisoners with doctoral degrees in agriculture, teachers, and medical doctors. He also recalled that the new lifers were asked to help residents by constructing roads and walkways and to help with the farming [5].

Not only were the prisoners used for manual labour, but also those with higher education were asked to teach students of local schools. A retired teacher from Green Island Primary school, Mr Dung-Jung Lin stated that the new lifers were assigned to give pupils extra lessons after school or during summer vacations. Students gained excellent examination result for entering their junior high schools. These new lifers made an enormous contribution to the education on Green Island. Thus the relationship between political prisoners and the local residents was subtle.

Most of the prisoners had been arrested without warning, with some sent directly to jail when their children were newly born or still young Their families suffered from not knowing when, or if, their sons, fathers, and husbands' would return. It was difficult to tell children the location of their fathers. $\mathrm{Mr}$ Chi-Hua Ker was arrested twice, once in 1951, and again in 1961. He was jailed for 17 years in total, accused of owning the book Dialectical Materialism, and of being 'leftist'. During this imprisonment his wife had to pretend to their children that he was working abroad. She did this by buying birthday cards which looked like those from overseas, and hoped to convince the children he was sending birthday wishes from another country [6]. Mr Wen-Gung Huang was arrested as soon as his wife delivered their third child, a girl. $\mathrm{He}$ was executed without ever seeing his newly born daughter and left five un-posted letters to his family. His daughter Ms Chun-Lan Huang finally received these letters after a period of 56 years. At the opening of National Human Rights Museum in 2011, she publicly read out her reply upon receiving these letters from the National Archives Administration, before breaking down with emotion. These arrests without warning left family members in shock and horrified at the implications.

The prisons are not only painful to former political prisoners, they are also the place where the victims spent their prime years. Mr Shu-Tsung Lin, a dentist, was sentenced to 12 years, after being arrested at night by the Military Police of the Ministry of Defence in 1969. He recalled that the prisoners were shackled together by the hands and ankles then sent to the boat for Green Island. He did not see his family again. Mr Shin-Fu Chung, sent to jail on Green Island, received a life sentence in 1956 and suffered interrogation, threats, and beatings. Mr Jung-Wen Shao also received a life sentence in 1969 at the age of 44 . He states that the Investigation Bureau came to the house and invited him for a 'talk'. He was brought with 11 other people in handcuffs, and asked to write a detailed biography. The authorities used torture to extract a confession, including slapping, forcing him to kneel on wooden poles, and pulling out his finger nails [7]. Mr Meng-Ho Chen (1930-) was a photographer, arrested while he was still a student at the Department of Fine Arts in National Taiwan Normal University. He was accused of joining the communist front organisation Academic Conference of Taiwan Province Labour Committee, which was deemed an "organisation of rebellion", and was sentenced to 15 years. He was ordered to work at the department photographing prison activities to give the impression of humanitarian care to the public. Nevertheless, he developed a better relationship with the prison authorities, and therefore had different experiences from other political prisoners, who often had to endure severe torture and interrogation. Depending upon their previous professions and special areas of knowledge, the prison became the place where the inmates spent their prime years, and in this way it stole the best part of the lives of the political prisoners.

\section{NARRATION AND RECONSTRUCTION ON THE ISLAND}

The memorial site functions not only as a sacred site and a shrine to a living man but also as a tourist attraction. Visitors to the expansive eco-friendly Green Island Human Rights Park now think that the GIHRMP is a leisure tourist product. This began with the institutional focus on tourism following the attention given to the conservation of the Oasis Villa.

The architecture of the Green Island Reform and Re-education Prison, the Oasis Villa, at the memorial sites certainly uncovers the experience which was available only to prisoners in the past. An administration building welcomes the visitors into an enclosed exercise yard surrounded with barbed wire. Visitors immediately feel the tension of authoritative control, and of being isolated. They then enter the two-storey radial plan cells. These are now preserved with all the cells open to the public. Visitors are led to the 
entrance of an atrium called the Bakua building. In the past political prisoners were held on the ground floor, the first floor being reserved for special needs (See Fig. 3).

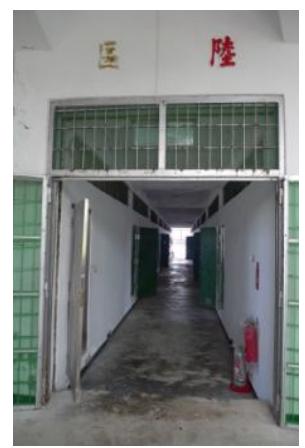

Fig. 3. The ground floor cells at oasis villa.

Here visitors are able to peep through the tiny opening in the door to look at a reconstruction of prisoners in the detention cell. I would argue that the interior conditions of the cell during Martial Law has been distortedly represented. What visitors can see is a "room" with a small number of prisoners who are sitting down looking peaceful, playing Chinese chess, reading books and talking. The fiction is evident when one sees that sunlight penetrates through the large windows. This is directly contradicted by prisoners' records of the difficult condition (See Fig. 4). The former political prisoner Mr Jin-Lang Gao described in his book the poor condition in cells: "It was to prevent prisoners looking at the blue skies and from escaping, the window were so tall and small. There was one prisoner who died due to the unbearable heat and lack of ventilation.”, “...especially at noon, it felt like being in a steaming pot." [8] The "explanatory gap" between prisoners and museum narratives has appeared, as well as the confusion of time, space and the representation displayed.

The narration that has been reconstructed leads to the absence of 'real' political prisoners within the site. The New Life Correction Centre, the Oasis Villa and other buildings are left as a "prisons in the past", with the Human Right Memorial indicating little of the history during Martial Law. The history that is linked with the imprisoned political prisoners in terms of geographical and spatial information, apart from the posters indicating victims' names on the wall, is absent. I argue that those who were associated with the site should have tribute paid to them in an authentic manner to generate the 'spirit of place'. As M. Shackley (2010) pointed out that it is difficult to see how 'spirit of place' would be retained, but it is easy to see the transition from shrine to theme park [9]. Although the political prisoner's voice is broadcast in the exhibition, the silence on the site produces a broken gap between the space, memory, people and the history. What is exhibited is a narration that serves nation-state identity by resisting interpretation.

Since the first group of New Lifers were deported to Green Island, the buildings of the New Life Correction Centre and the Oasis Villa have gone through several stages of alteration, demolition, and extension. The aim of the museum site of the former New Life Correction Centre has been to exhibit the life of political prisoners by facilitating the rebuilding of cell barracks from old photographs and sketch drawings by one prisoner. A former gathering space, Chung-Cheng Hall is located at the site of New Life Correction Centre, and is now a space that shows the history of the dark past. It houses an exhibition of a large-scale model of the New Life Correction Centre made with reference to a painting by the former political prisoner $\mathrm{Mr}$ Meng-Ho Chen, in addition to exhibiting models of the daily life of the prisoners. The displayed objects unveil the cell life in the past, but with little contextualised references to the actual site. Mr Meng-Ho Cheng had a good relationship with the prison authorities during his incarceration and is therefore willing to be involved in this reconstruction of the past. The organiser of the memorial park, and the company employed to design the exhibition, have taken for granted his perspective on the experiences in the prison.

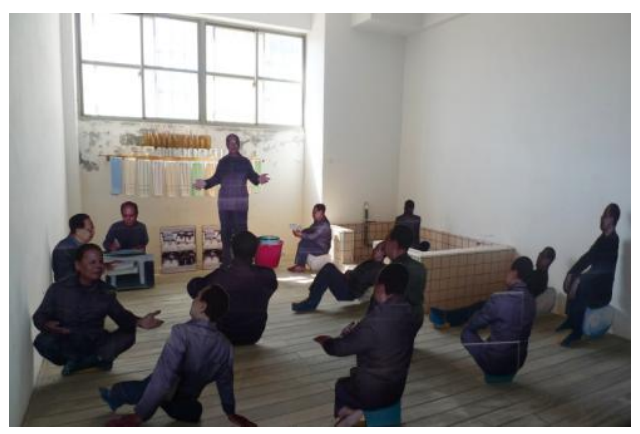

Fig. 4. Displayed imaginative scene of the cell

In this exhibition visitors encounter a large scale model displayed on the floor in the centre of the space accompanied by short animated simulations. Visitors can watch videos on mounted screens with testimonies delivered by former political prisoners, and examine a series of small models displayed in the exhibition. Here visitors need to identify the constituents parts of the site by watching videos and situate the prisoners within the model. From the exhibition of former political prisoners' personal narratives, visitors are asked to perceive the daily routine carried out during imprisonment. However, this was told partially from the testimony of 'some' former political prisoners who were selected to participate in prison labour. These were the prisoners who had shorter sentence or had developed a better relationship with the prison warders (See Fig. 5). I argue that, with the lack of the various experiences of different former political prisoners, especially those who experienced dramatically different conditions depending on their crime and willingness to co-operate with the prison, visitors experience a one-sided history.

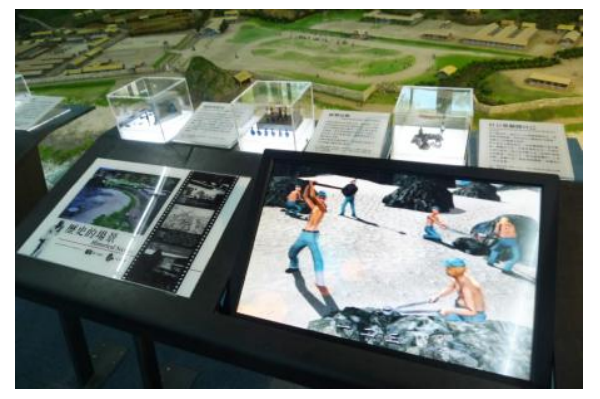

Fig. 5. Hard labour displayed through animated screen. 


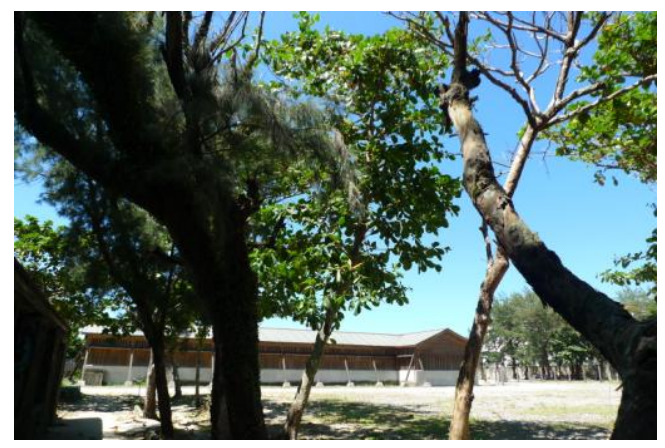

Fig. 6. Reconstructed cell barracks of the third brigade in the background.

The Exhibition Area in the reconstructed cell barracks displays the New Lifers' existence in the New Life Correction Centre. This was reconstructed in 2008 according to the technical drawings, again by former political prisoner Mr Meng-Ho Chen, to accommodate most of the exhibitions. Narration of the past on the island is reconstructed via the unitary perspectives of one former political prisoner, and without any authentic indication of geographical information linked to the experiences of other former political prisoners. This runs the risk of misleading visitors with a distorted history of the past. This is in addition to the exhibition at the gathering hall of the New Life Correction Centre which stems from the same perspective. The reconstructed cell barracks were built to imitate those where the Third Brigade was originally located, and comprise one longitudinal and four horizontal barracks. The Exhibition inside focuses on how new lifers were confined and imprisoned (See Fig. 6).

Starting at the first longitudinal barrack the visitors enter a space and are introduced to a simulation of a classroom where numerous prisoners are sitting down to receive instruction. The exhibition service area is at the centre of the barrack, with an information station set alongside. This functions as the search hub network for name lists of former political prisoners, oral testimonies and videos. At the end of the room is a permanent exhibition titled "Reconstructing History", which introduces the Memorial Site at its inception in 2001 and completion in 2009. This mainly focuses on introducing the establishment of the Memorial Park using text panels. The Exhibition in the 4 cell barracks are associated with the routines of new lifers, with one of the barracks exhibiting scenes of "Labour and Thought Reform" by using wax figures to represent the prisoners hammering rocks in the pigpen grass hut.

Another of the barracks is used to exhibit New Lifer's dormitory cells, again using wax mannequins to represent conditions for the inmates during the 30 minutes to one hour of "free" activities before "light out" at night. During this hour, some of the New Lifers played violin or guitar. "New Lifers would talk, or read if one preferred being left alone" said the former political prisoner Mr Ching-Hsiu Lu, who received a life sentence in 1953 (he was later granted amnesty when President Dung-Hui Lee was inaugurated in 1990). Each of the squadrons had 6 dormitory rooms for inspectors in the front of the cell area. The exhibition leaflet states that the size of each bed was 1.35 meters, and this was to accommodate 3 to 4 prisoners. There were from 120 to 160 prisoners in one dorm cell. However the exhibition does not show the confined and crowded nature on site. According to the testimony of former prisoners, this was the only free time during the whole day, and it was at night (See Fig. 7).

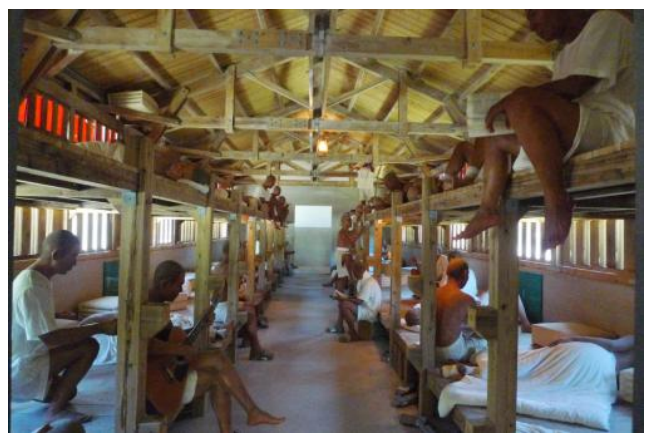

Fig. 7. Wax mannequins showing the one hour free time before "light out."

Yet visitors see the scene in a bright and spacious dorm which provides misleading information concerning how former political prisoners lived during imprisonment. The confusion of time and space provides a fragmented and distorted history to visitors. The critical points concern how these conditions are displayed and what these imagined life scenes are supposed to convey.

The second horizontal barrack holds an exhibition under the title of "In the Prime of their Lives", which displays archives, documentation film and photographs of those victims who were falsely convicted under the totalitarian regime. This is based on case files. Visitors need to access the archive database to view testimonies where former political prisoners tell their stories. These are disconnected from the exhibition, whereas the art works created by the prisoners are displayed in the space to provide atmospheric backgrounds, with guilt at imprisonment, and lists of accusations, written in calligraphy on white fabric. One can question how what happened to the individual victims in association to the site can be raised. How are the spaces exhibited relating to the course of the period of Martial Law? The sorrow of the background music, and the photographs displayed as an unmediated experience, allow the visitors to leave with narratives disconnected from the context. All that is left is a personal reinvention of the past.

The narrative of history is composed by a thread of objects, typical of the collection (i.e. instruments made by prisoners, photographs, clothes, crafts.) The artefacts are displayed in the categories of hand-crafted instruments, woodworks, music compositions, and so on. They are interpreted as "groups" of objects produced by prisoners. A strong message delivered by the centre is that centred on the collective, the prisoners as a "whole", instead of individual memory.

Struggle for control over sites of torture and disappearance both resonate with the unresolved past political tensions of the era of Martial Law. The prison is bound tightly not only to political prisoners, but also to their families. It cannot exclude those who also carry terrible memories of being "secondary victims" of the security apparatus [10].

\section{RE-PRESENTED HISTORY}

Heritage is intertwined with identity and territory, where 
individuals and communities are often in competition or outright conflict. Conflict may occur over issues of indigenous land and cultural property rights, or between ethnic minorities and dominant majorities who dispute the right to define and manage the cultural heritage of a minority. The question that H. Silverman and D. F. Ruggles (2007) raised concerns who should control the stewardship and benefit of cultural heritage [11]. E. Beneki (2012) noted that with new museology developments, the concept of the museum goes beyond the particular physical place to define an open area that reflects a certain cultural heritage approach [12].

The history that the memorial site itself has delivered is "for" the nation, not "of" the victims, their families, and people. The history that is presented is an approach that draws visitors to overcome the past with general and unspecific stories in relation to the witness of the place and victims. The name list exhibition shows that, up to 1999, the number of victims of the period of Martial Law is 8,296. The victims listed in the exhibition is therefore not equivalent to the actual number of prisoners who are associated with the site. There is insufficient explanation of how spaces are transformed in terms of function and time of alteration.

The prisons functioned as places to segregate the opposition from mainstream society, through the use of perimeter walls, internal fences, cellblocks. The prison and its inhabitants, both inmates and warders, were physically insulated from the outside, forming a society within a society [13]. For political prisoners on Green Island, this was not quite the case, for, as a result of their professional background, they were ordered to assist local residents at certain times during their imprisonments. Therefore, the memories that built up between the people on Green Island and the "new lifers" are particularly different. For most of the prisoners, the memory of the imprisonment is defined by bitterness towards hard labour, with thoughts and speech controlled, and unbearable living conditions. For the inhabitants of Green Island, the memories will be different.

The site has decreased the spatial contrast between interior and exterior of the prison by providing easy accessibility, and by producing a non-hierarchical approach to prison spaces. Instead, visitors misinterpreted the experience as similar to being in military service. The spatial context also leads visitors to interpret the spaces regardless of their geographical and historiographical orientation. In addition to the disappearance of original cells, visitors have been misled as to the conditions the political prisoners endured in the past, leaving too much to the imagination. The history has been represented by aesthetically pleasing objects, and this raises concerns. There is insufficient information concerning each period during which the prisons functioned and were built. The result may be that negative memories will be washed away for visitors.

There are three aims for the Green Island Human Rights Memorial Park. These are:

1) Understand the history of the striving for human rights in Taiwan;

2) Be aware of the importance of protecting ecoenvironment; and

3) Build up a culture of freedom and peace.

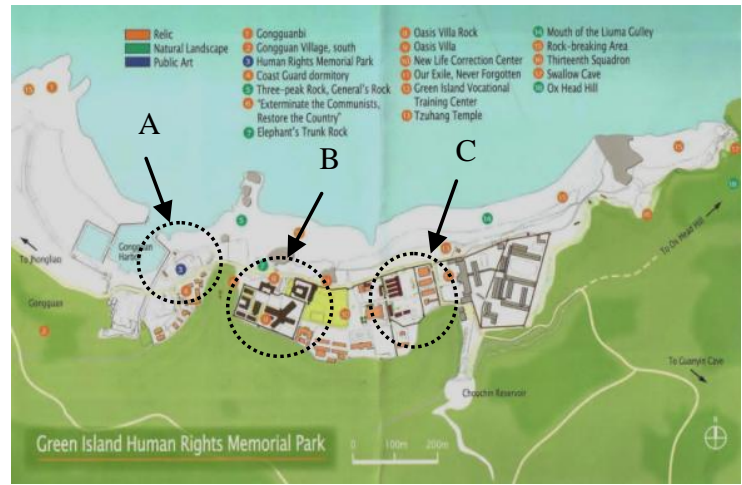

Fig. 8. Current plan of the green island human rights memorial park. courtesy of gihrmp with additional indication by author.

As shown in Fig. 8, visitors first entered the site from A, the Human Rights Memorial, a sunken space which is inscribed with the names of victims during Martial Law. From there visitors naturally approach towards B, the Oasis Villa and then last, the New Life Correction Centre. The arrangement of the experience of the space is an inverted experience of that of the former political prisoners and reverses the chronological sense of the history.

When the visitor enters the New Life Correction Centre, it is without being informed that the cell barracks are reconstructed, and are now used to "house" the pigpen hut and scenes of labour, and there is no indication of the original functions (See Fig. 9).

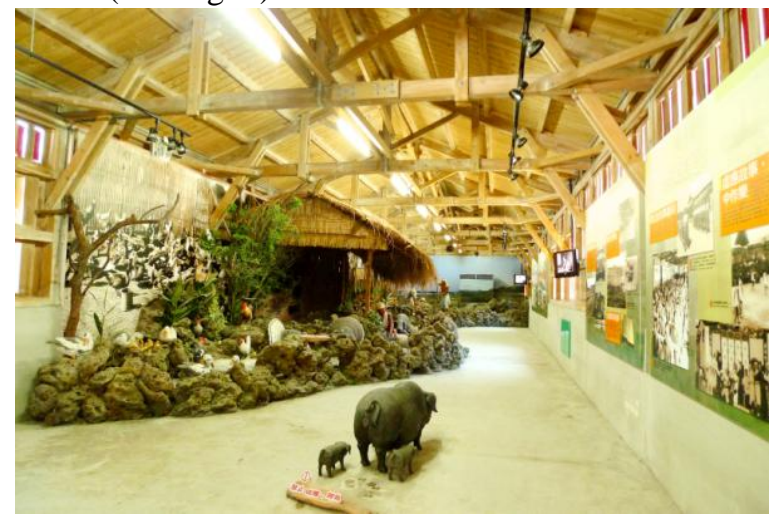

Fig. 9. Displayed scenery detached from the original site.

I argue that the exhibited narrative of prison life generates an ambivalence which lies beneath the real history of prisoners and the proposed history for visitors. During the period of Martial Law, names, locations and spaces of former detention centres almost vanished from the conversations of the social elite. This silence continues in the absences at the heart of the site. To reach an understanding of the treatment of victims of national trauma it is necessary to recognise as victims, not only those who suffered torture or disappearance, but also their families, including children who may never have known their parents.

\section{CONCLUSION}

I have raised arguments concerning the manner in which representation of the exhibited history in the political prisons has been disconnected from the memories of individuals. The prisons have been renamed as a Human Rights Memorial Site. 
It is obvious that the history has been constructed upon the collective interpretation of the darkest past of Taiwan by unifying memory. The exhibition reveals the buildings, the objects, in a specific manner, while obscuring the chronology in relation to the site. This also holds true for most of the victims, who are seen to be silent and disconnected from the exhibited scenes. It is also found that the disengagement between the public and the individual history on Green Island may be the reason that the painful memories of former political prisoners do not play an essential role in terms of the exhibits and narration that is associated with the site. The site of the former prison has delivered a gap between the authentic past and the way the exhibition reveals the unitary history from one perspective. The connection with the actual authentic stories has been lost in terms of the spaces and the 'spirit of place'

To direct visitors towards the past by careful indication to the site would enhance the close link to our past. It is vital that this site acts as mediator to how our history is interpreted and represented. It is also vital it is used in conjunction with authentic history to make the site more relevant and intellectually integrative to the visiting public.

\section{REFERENCES}

[1] S. A. Kan and W. M. Morrison, "US. Taiwan Relationship: Overview of policy issue," CRS Report for Congress, Taiwan, 2013.

[2] M. S. Ho and J. Broadbent, "Introduction to Taiwanese Society, Culture, and Politics" in East Asian Social Movements: Power, Protest, and Change in a Dynamic Region, J. Broadbent and V. Brockman, Ed., 2011.

[3] GIHRMP, Master Plan of Green Island Human Rights Memorial Park, Council for Cultural Affairs, 2006.

[4] C. H. Ker, Taiwan, Island of Prison-Chi-Hua Ker's Memoir, $1^{\text {st }}$ ed., Kao Siung City, Taiwan: First, 2002, pp. 119-127.

[5] The Light of Green Island, Video records of the Green Island Human Rights Memorial Park, Council of Cultural Affairs, 2011.

[6] C. H. Ker, Taiwan, Island of Prison-Chi-Hua Ker's Memoir, $1^{\text {st }}$ ed., Kao Siung City, Taiwan: First, 2002, pp. 119-127.

[7] GIHRMP, A Day on Green Island-Oral History Documenting Former Prisoners and White Terror History, Video records of the Green Island Human Rights Memorial Park, National Taitung Living Art Centre, Taiwan, 2009.
[8] J. L. Gao, Tai-Yuan Fung Yun- Incidents of Revolution, Taiwan: Chien-Wei Pub, 1991.

[9] M. Shackley, "Potential Future for Robben Island: shrine, museum or theme park?" International Journal of Heritage Studies, vol. 7, no. 4, pp. 355-363, 2001.

[10] M. Wyndham and P. Read, "Filling the void of trapped memories: the liberation of a pinochet centre of torture," Journal of Iberian and Latin American Research, vol. 18, no. 1, pp. 41-54, 2012.

[11] H. Silverman and D. F. Ruggles, Culture Heritage and Human Rights, New York: Springer, 2007, pp. 3-29.

[12] E. Beneki, J. P. Delgado, and A. Filippoupoliti, "Memory in the maritime museum: objects, narratives, identities", International Journal of Heritage Studies, vol. 18, no. 4, pp. 347-351, 2012.

[13] M. Dewar and C. Fredericksen, "Prison heritage, public history and archaeology at Fannie bay gaol, northern Australia," International Journal of Heritage Studies, vol. 9, no. 1, pp. 45-63, 2003.

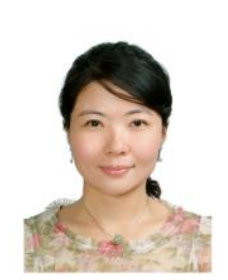

H. W. Lin was born in Taipei Taiwan, on May 5 1974. She earned her Ph.D. in architecture 2008 at National Cheng Kung University in Taiwan, her received M.A. in 1999 and B.A. hons in 1997, both in interior design, from Manchester Metropolitan University in the UK. She joined the National Cheng Kung University faculty in 2012 as an assistant professor in the Institute of Creative Industries. Prior to that she was a faculty member at the Kun Shan University of Technology at the Department of Spatial Design in 1999-2012. She was awarded the Best Teaching in 2011. She was invited to be the visiting scholar at the Centre of Humanity and Social Science in the National Science Council in Taiwan in July, 2013 as well as the Visiting Scholar in Fudan University in China in April, 2013. Her experiences and expertise has enabled her to contribute over 30 research papers to conferences and Journals. These have mainly focused on issues relating to the sites and places that are associated with significant events, for their social and cultural meanings. Her doctoral degree dissertation was funded and awarded by Cultural Bureau in 2008. Her research outcomes include the book chapter published in Patrimoine en devenir ; penser et pratiquer l'esprit du lieu in Montréal 2010 under the title of "Reveal Spirit of Place by War Monumentality and Its Monumental Meanings: Purpose of Monument Erection in Kinmen Island, Taiwan", and the paper published in the Journal of Conservation of Cultural Heritage by Cultural Bureau in Taipei 2010 under the title of "The 'Memorised' and 'Forgotten' Difficult Past of Holocaust: Rethinking the Authentic Site to Traumatic Cultural Heritage".

Dr. Lin has been a member of the International Council on Monuments and Sites (ICOMOS) since 2013 and the Society of Architectural Historian of Taiwan since 2008, and was elected as Director in 2010. She has also been elected as director of the Foundation of Historic City Conservation and Regeneration in 2012. She has been a member of the Architectural Institute of Taiwan since 2005 . 